on one other patient still showed a normal record, but in another a minimal left temporal abnormality was found on the second E.E.G.

\begin{tabular}{|c|c|c|c|c|}
\hline $\begin{array}{l}\text { Case } \\
\text { No. }\end{array}$ & $\begin{array}{c}\text { Interval } \\
\text { after Fits }\end{array}$ & Result & $\begin{array}{c}\text { Repeat E.E.G. } \\
\text { Interval }\end{array}$ & Result \\
\hline$\frac{1}{2}$ & $\begin{array}{l}6 \text { days } \\
16 \text { days }\end{array}$ & $\begin{array}{l}\text { Normal } \\
\text { Mildly abnormal theta } \\
\text { activity, maximal in } \\
\text { left temporal leads }\end{array}$ & 3 months later & No change \\
\hline $\begin{array}{l}3 \\
4\end{array}$ & $\begin{array}{l}3 \text { months } \\
18 \text { days }\end{array}$ & $\begin{array}{l}\text { Normal } \\
\text { Sharp waves and diffuse } \\
\text { theta favours idiopathic }\end{array}$ & - & \\
\hline $\begin{array}{l}5 \\
6\end{array}$ & $\begin{array}{r}5 \text { days } \\
16 \text { days }\end{array}$ & $\begin{array}{l}\text { Normal } \\
\text { Normal }\end{array}$ & 2 weeks & Normal \\
\hline 7 & 12 days & Normal & 2 months later & $\begin{array}{l}\text { Minimal left } \\
\text { temporal ab- } \\
\text { normalities }\end{array}$ \\
\hline 8 & 9 days & $\begin{array}{l}\text { Paroxsymal discharges on } \\
\text { overbreathing " sugges- } \\
\text { tive of epilepsy " }\end{array}$ & - & \\
\hline 9 & 14 days & Normal & - & \\
\hline
\end{tabular}

\section{Follow-up}

Patients have been followed for a minimal period of six months, and two (Cases 6 and 7) have had further epileptic attacks. In one the depression has also recurred and has necessitated admission to a mental hospital.

\section{Discussion}

Our experience over a period of 16 months shows that epileptic fits are by no means uncommon in patients on antidepressant drugs. In none of them had these drugs been thought responsible for the fits, and a diagnosis of hysteria had been made in three cases. It is noteworthy that in all the cases predisposing factors for epilepsy were present. Although E.C.T. had not previously been reported as predisposing to fits, most neurologists have seen epilepsy following this mode of treatment. In three cases only a few tablets of amitriptyline had been taken, suggesting a drug idiosyncrasy.

Our experience confirms that of Betts et al. (1968, and in our view if any of the factors we regard as predisposing to epilepsy are present in the patient's history-namely, previous or family history of attacks, previous brain damage or E.C.T., cerebral arteriosclerosis, alcoholism or barbiturate withdrawalwe suggest that an anticonvulsant drug should be simultaneously administered. The most suitable in our opinion is phenytoin.

As two of our cases were already taking chlordiazepoxide it is clear that the anticonvulsant action of this drug is insufficient. The road accident that occurred in Case 7 draws attention to the inadvisability of allowing patients to drive a car while on the drug, unless they are also taking an anticonvulsant.

We would like to thank Dr. F. C. Clayton, of Merck Sharp and Dohme Ltd., and Dr. J. K. Galbraith, of Geigy Ltd., for their interest, and Dr. Donald Scott, of the E.E.G. department, the London Hospital, for his help in the preparation of this paper.

\section{REFERENCES}

Betts, T. A., Kalra, P. L., Cooper, R., and Jeavons, P. M. (1968). Lancet, $1,390$.

Davison, K. (1965). Electroencephalography and Clinical Neurophysiology, 19, 298.

Kiloh, L. G., Davison, K., and Osselton, J. W. (1961). Electroencephalography and Clinical Neurophysiology, 13, 216.

Vernier, V. G. (1961). Diseases of the Nervous System, 22, May suppl., p. 7

Winfield, D. L., and Aivazian, G. H. (1962). Diseases of the Nervous System, 23, 517 .

\title{
Plasma Factor IX Levels in Patients Given Hexoestrol or Stilboestrol to Suppress Lactation
}

\author{
C. A. HAKIM,* M.B., B.CH. ; M. G. ELDER, $\dagger$ M.B., F.R.C.S., M.R.C.o.G. ; D. F. HAWKINS, $\ddagger$ D.sC., M.B., M.R.C.o.G.
}

\begin{abstract}
Cummary : A single injection of hexoestrol, $45 \mathrm{mg}$., is effective in suppressing lactation. Given in this way hexoestrol causes a small rise in plasma factor IX levels, of shorter duration than that produced by a customary and equally effective oral course of stilboestrol. With hexoestrol the plasma factor IX levels reverted to normal by the sixth day of the puerperium.
\end{abstract}

\section{Introduction}

Oral administration of stilboestrol for the suppression of lactation has been reported to be associated with an increased

\footnotetext{
* Research Assistant and Honorary Registrar.

+ Registrar and Tutor.

$¥$ Senior Lecturer and Honorary Consultant Surgeon.

Institute of Obstetrics and Gynaecology, Hammersmith Hospital, London W.12.
}

incidence of thromboembolic episodes in the puerperium (Daniel et al., 1967). Stilboestrol administration is also known to cause an increase in the level of plasma factor IX in puerperal women (Daniel et al., 1968).

The present work consists of a study of factor IX levels in the plasma of three groups of puerperal women-some in whom lactation was suppressed with intramuscular hexoestrol or oral stilboestrol and others in whom lactation proceeded.

\section{Methods}

The patients investigated were primigravidae under 30 years of age. All had a normal labour, delivery, and puerperium. There was no history of liver disease or of thromboembolic episodes. No such episodes were encountered during this study. Patients who were lactating acted as a control group. 
Patients who had lactation suppressed were given either (a) hexoestrol, $45 \mathrm{mg}$. intramuscularly as a single dose, or (b) stilboestrol, $10 \mathrm{mg}$. orally three times a day for one day, twice a day for one day, and then daily for four days. Both regimens were started within 24 hours of delivery.

The technique used to estimate factor IX was the onestage method described by Dacie and Lewis (1968) adapted from Hardisty and Macpherson's (1962) procedure for factor VIII assay. A kaolin-activated system, consisting of stored $\left(-20^{\circ}\right.$ C.) plasma from a patient with severe Christmas disease, together with adsorbed fresh normal plasma supplying factors V and VIII and phospholipid, is used. The corrective effect of the test plasma on the time taken for fibrin clot formation is compared with that of pooled plasma from normal individuals. The mean value in non-pregnant adults is usually taken as $100 \%$, with a normal range from 50 to $150 \%$.

Blood samples were taken by venepuncture into citrate tubes, avoiding stasis. Plasma was separated within an hour by centrifugation for three minutes at 3,000 r.p.m., frozen to

$-20^{\circ}$ C., and tested within three days. Factor IX and partial thromboplastin time with kaolin (P.T.T.K.) estimations were carried out on plasma obtained from $4.5 \mathrm{ml}$. of blood added to $0.5 \mathrm{ml}$. of $3.8 \%$ sodium citrate. The "normal plasma" was obtained under similar conditions, pooling plasma from not less than three healthy male or non-pregnant female subjects. The reproducibility of the method was verified by estimations on duplicate specimens, identified by numbers whose meaning was unknown to the person performing the tests. Samples from all three groups of patients were assayed together so that any assay variability would affect all three groups.

Standard methods were employed to estimate clotting-time, haemoglobin, packed cell volume, mean cell haemoglobin concentration, platelet count, and prothrombin consumption index. These tests were performed on each blood specimen studied.

A total of 156 factor IX estimations were performed on 46 mothers: hexoestrol group, 63 estimations on 16 patients; stilboestrol group, 36 estimations on 13 patients; and lactating group, 57 estimations on 17 patients. Where possible serial investigations were carried out on each patient, and most of those who were given oestrogen had factor IX estimations carried out before beginning treatment.

Mean age, duration of labour, and estimated blood loss at delivery of the patients studied are shown in the Table. The means of the three groups do not differ significantly.

Mean Age, Duration of Labour, and Estimated Blood Loss at Delivery of Patients Studied

\begin{tabular}{|c|c|c|c|}
\hline & Hexoestrol & Stilboestrol & Lactating \\
\hline $\begin{array}{lcc}\text { No. of patients } & \ldots & \ldots \\
\text { Mean age (years) } & \ldots & \\
\text { Mean duration of labour (hours) } \\
\text { Mean estimated blood loss at } \\
\text { delivery (ml.) } & \ldots & . .\end{array}$ & $\begin{array}{r}16 \\
21 \cdot 3 \\
15 \cdot 3 \\
144 \cdot 6\end{array}$ & $\begin{array}{c}13 \\
21 \cdot 3 \\
14 \cdot 3 \\
146 \cdot 5\end{array}$ & $\begin{array}{c}17 \\
20 \cdot 9 \\
10 \cdot 6 \\
133 \cdot 9\end{array}$ \\
\hline
\end{tabular}

\section{Results}

Either the single intramuscular injection of hexoestrol given within 24 hours after delivery or the course of oral stilboestrol was found to suppress lactation effectively in all patients so treated.

Mean factor IX levels, expressed as percentages, for the three groups during the first 10 days after delivery are shown in the Chart. The average factor IX level on the first puerperal day, before initiation of treatment, was a little higher in the stilboestrol group of patients, but the variation in this group was greater than in the other two groups and the group means did not differ significantly. Values for days 5 and 6 were pooled, as were those for days 7 and 8 and for days 9 and 10 .

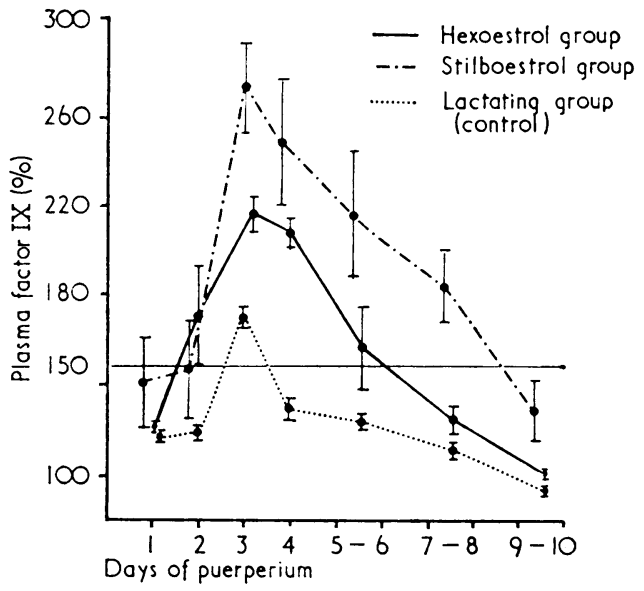

Mean plasma coagulation factor IX levels in the puerperium-effect of hexoestrol or stilboestrol used to suppress lactation. The line at $150 \%$ represents a customary upper limit of normal for non-pregnant a customary upper limit of normal for non-pregnant
patients. The standard errors shown represent largely patient-to-patient variation.

A modest rise in mean plasma factor IX level, with a maximum of $170 \%$ on the third puerperal day and reversion to within the normal range-that is, to less than $150 \%$-by the fourth day, occurred in women in whom lactation was allowed to proceed. When hexoestrol was given, the rise in mean factor IX level was rather greater, reaching a maximum of $215 \%$ on the third day, but the average level had declined so that it no longer differed significantly from the level in lactating patients by the fifth and sixth puerperal days. This was in contrast to the mean levels in patients given stilboestrol, in whom the initial rise was to $275 \%$ on the third day, and the average factor IX level was maintained above the level in lactating patients until after the eighth puerperal day, at least two days after administration of the drug had ceased.

Statistical analysis showed that the difference between the hexoestrol and lactating groups of mothers was significant on days 2,3 , and 4 only $(P<0.01)$. The difference between the stilboestrol and lactating groups of mothers was significant from day 3 to days 7 and $8(P<0.05)$. Factor IX levels were significantly higher in the stilboestrol group than in the hexoestrol group on days 7 to $10(\mathrm{P}<0.01)$.

The estimations of clotting-time, haemoglobin, packed cell volume, mean cell haemoglobin concentration, platelet count, and prothrombin consumption index were all within normal limits. These values did not differ significantly between the three groups of patients under study.

\section{Discussion}

In lactating women we found a transient rise in mean plasma factor IX levels from the already raised levels of late pregnancy on the third puerperal day only. This agrees with the results of Daniel et al. (1968). We have shown that after a single 45-mg. injection of hexoestrol factor IX levels are significantly increased over those in control patients until the fourth day. Although the $90-\mathrm{mg}$. course of oral stilboestrol administered over a six-day period which we employed was only half the dose given by Daniel et al. (1968), significantly raised plasma factor IX levels were still present until after the eighth day of the puerperium.

In animal experiments it has been shown that activity of factors IX, XI, and XII is essential for the development of 
a thrombus (Wessler and Reimer, 1960). Daniel et al. (1968) suggested that very high levels of plasma factor IX may be related to the development of puerperal venous thrombosis. It would appear reasonable to avoid the use of therapeutic agents which give rise to excessive or prolonged increases in factor IX levels during the puerperium. If lactation is to be suppressed with oestrogen it is preferable to use the smallest dose that proves effective.

The present study has shown that intramuscular hexoestrol has a theoretical advantage over oral stilboestrol in that the increase in factor IX levels is not so great and is of a shorter duration. With most hexoestrol-treated patients plasma factor IX has reverted to normal by the time they leave hospital.
We are grateful to Dr. W. R. Pitney for instruction in the technique of factor IX estimations and for his advice at all stages, and to Ortho Pharmaceutical Limited for a supply of factor-IXdeficient plasma and for financial assistance with the study.

\section{REFERENCES}

Dacie, J. V., and Lewis, S. M. (1968). Practical Haematology, 4th ed., p. 297. London, Churchill.

Daniel, D. G., Campbell, H., and Turnbull, A. C. (1967). Lancet, 2,

Daniel, D. G., Bloom, A. L., Giddings, J. C., Campbell, H., and Turnbull, A. C. (1968). British Medical fournal, 1, 801.

Hardisty, R. M., and Macpherson, J. C. (1962). Thrombosis et Diathesis Haemorrhagica, 7, 215.

Wessler, S., and Reimer, S. M. (1960). Fournal of Clinical Investigation, $39,262$.

\title{
Transplacental Passage of Fetal Red Cells in Abortion; Increased Incidence after Curettage and Effect of Oxytocic Drugs
}

\author{
J. KATZ,* м.в., в.CH.
}

British Medical fournal, 1969, 4, 84-86

Summary : In a study of early abortions (less than 16week pregnancies) no significant increase in fetomaternal haemorrhage was found in patients having either threatened or incomplete abortions. A statistically significant increase in fetal cells in the maternal circulation, however, occurred after curettage. The administration of oxytocic drugs in conjunction with curettage in cases of incomplete abortion did not increase the incidence of transplacental passage of fetal erythrocytes when compared with curettage alone. Of the 81 patients curetted following abortion four had a feto-maternal haemorrhage of more than $0.2 \mathrm{ml}$. The largest amount of fetal blood found in the maternal circulation was 0.4 to $0.5 \mathrm{ml}$. Preliminary data evaluating the indirect Coombs test and enzyme-treated red cells in Rh-negative post-abortion cases suggest that this amount of blood is not a primary immunizing dose but a "booster" to preformed antibody.

\section{Introduction}

$\mathrm{Rh}$-immunization in pregnancy is regarded today as a preventable condition. At a symposium held in New York in October 1967 it was concluded that Rh-antibody given to an $\mathrm{Rh}$-negative mother within three days of the delivery of an $\mathrm{Rh}-$ positive infant prevented primary immunization (Rosenfield, 1968). Though most significant feto-maternal transfusions occur during or just after labour (Woodrow et al., 1965 ; Zipursky et al., 1963b), it has been shown by Zipursky et al. (1963b) and Cohen and Zuelzer (1964) that there are small fetomaternal transfusions during the early months of normal pregnancies. The early feto-maternal transfusions have prompted Zipursky and Israels (1967) to administer small doses of Rhantibody during the third trimester in $\mathrm{Rh}$-negative pregnancies, to prevent $\mathrm{Rh}$-sensitization during the pregnancy.

Abortion has been incriminated as a mechanism for Rhsensitization (Gellén et al., 1965 ; Matthews and Matthews,

- Senior Haematologist, South African Institute for Medical Research, Jolrannesburg.
1969), and it has been suggested that non-immunized Rh-negative women who abort should receive prophylactic $\mathrm{Rh}$-antibody (British Medical fournal, 1968). These reports, ccupled with the finding that traumatic manipulations in pregnancy, amniocentesis (Zipursky et al., 1963a), caesarean section, and manual removal of the placenta (Zipursky et al., 1963a) are associated with massive feto-maternal haemorrhage, led to the present investigation of feto-maternal haemorrhage in early abortion, and its incidence after curettage, and of the effect of administering oxytocic drugs. Increased passage of feto-maternal red cells after abortion, in sufficient quantity to induce immunization or sensibilization, would necessitate the administration of Rh-antibody to post-abortion, Rh-negative mothers.

\section{Methods}

The technique used to demonstrate fetal cells in the maternal circulation was a modification of the acid-elution method of Kleihauer, Braun, and Betke (1957). The fetal erythrocytes containing haemoglobin $\mathrm{F}$ stain a darker red colour than the maternal erythrocytes. This is an accepted method for enumerating fetal red cells in the maternal circulation (Zipursky et al., 1959; Finn et al., 1961). Duplicate slides of blood smears were examined from all subjects, and two control slides were set up with each batch of slides, one from a normal nonpregnant subject and one from a subject with a known high fetal haemoglobin content (namely, from a young infant's blood or cord blood). With a low-power lens 50 fields-giving an approximate count of 150,000 cells-were counted in each slide. The mean of the two slides was taken as the fetal erythrocyte score. A fetal cell score ${ }^{1}$ of 1 was recorded if one fetal cell was counted in both slides. If a fraction resulted when more than one fetal cell was counted the next highest digit was taken as the fetal score. Five fetal red cells is equivalent to about $0.2 \mathrm{ml}$. of fetal blood in the maternal circulation (Woodrow et al., 1965). To ascertain with certainty the embryonic blood picture, the acid-elution technique of Kleihauer was performed on cord blood of a 12-week fetus 